\title{
On the Application of Teacher Expectancy Effect in English Teaching
}

\author{
Xing Chihong \\ Foreign Languages School \\ Linyi University \\ Linyi, China \\ shidaimaomi@163.com
}

\begin{abstract}
Rosenthal Effect (Pygmalion Effect) is a form of self-fulfilling prophecy and has been applied to researches in many fields in recent years. It is the application of Rosenthal Effect in the education field. Teacher expectation is teacher's expectation and concern for students on the knowledge of them. Teacher Expectancy Effect is the influence or result upon students on the basis of teacher's expectations. Thus, the effect on student progress is of great importance in educational research. That is, students' achievements have a certain relation to teachers' expectations. Teacher Expectancy Effect has positive or negative effect and nongeneralization. The influential factors and transmissive ways are also involved in this paper. More emphasis is put on the applications of Teacher Expectancy Effect in English teaching. Various measures should be taken to help the formation of suitable and positive Teacher Expectancy Effect so as to improve English teaching more effectively.
\end{abstract}

Keywords-Teacher Expectancy Effect; factors; application; various measures; English Teaching

\section{INTRODUCTION}

The Rosenthal Effect or Pygmalion Effect is a form of self-fulfilling prophecy, and it refers to such phenomenon: the greater you put expectation on people, often children, students or employees, the better they will do to meet your expectation. The reason is that those people with expectation placed by their parents, teacher or employee will probably internalize the negative label with positive labels, and study or work harder than ever before, and eventually succeed in their field. This expectancy effect is often connected with education and social class in the filed of sociology.

Robert Rosenthal and Lenore Jacobson studied and explained the Rosenthal Effect by their experiments. They concluded that if a teacher had positive expectation for his students, the students would be encouraged unconsciously to do better to show enhancement. Rosenthal predicted that teacher expectation is influential to students, to their selfconcept, motivation and achievements. The Rosenthal Effect demands that teachers should pay close and more attention to every student, encourage them not only by words, but most importantly, by behavior unconsciously, and trust students' latent energy, and look to education and students in a quite different and positive way so as to establish new outlook of education and students (Scott 2001).[1-17]

According to Thomas L. Good (1987), professor of educational psychology, university of Missouri-Columbia, teacher expectation is defined as "inferences that teachers make about the future behavior or academic achievement of their students, based on what they know about these students now." (Matters 2013) [2] Ever since Rosenthal and Jacobson's experiments, people have been putting more and more interest and efforts on the topic of Teacher Expectancy Effect. Much progress has been made on teacher expectation in class not only on the theoretical study but also practical study, and many study methods and models had been put forward.

A teacher plays a vey important role in the growth of his students. However, how to treat students properly and rightly still lies in the dark though there are still many voices in this respect. The essay is to examine the literature dealing with the formation and the Teacher Expectancy Effect on students. This essay focuses on factors, transmissive ways and the application of Teacher Expectancy Effect in English teaching and helps teachers to know their expectations and behaviors have powerful effects on students and encourage them to achieve more in the their academic experience.

\section{FEATURES ,TRANSMISSIVE WAYS AND INFLUENTIAL FACTORS OF TEACHER EXPECTATION}

\section{A. Features of Teacher Expectation}

Teacher expectation has two outstanding features: positive or negative and non-generalization. First, let's focus on positive and negative expectations. "As we grow up and in the process of confronting disappointment, we develop negative expectations, mostly as a way to protect ourselves." (Scott 2001) [1-19] This development of negative expectations as student's nature can be greatly amplified if teachers treat their classroom children in the same manner. Rosenthal's experiment in the effect of teacher expectation also made it clear that teacher's expectancy is a kind of great strength of education. The positive effect, certainly are beneficial to the study of students while the negative one play conversed influences.

The other feature of teacher expectation is "nongeneralization". Non-generalization refers to such phenomenon that teacher expectation only works on those students who can receive teacher's expectations. In general, teachers will show unconsciously their kindness to "good students" and dislike to so-called "bad students". This unconscious and subtle attitude can easily be felt by students and influence their immature psychological development. Therefore, it is imperative that teachers should try their best not to form such differential expectations to the students' benefits. 


\section{B. Transmissive Ways of Teacher Expectation}

Teacher expectation has two transmissive ways: verbal way and non-verbal way. Verbal way means that teachers express their praise, approval, encouragement and even criticism with words and expressions. In a non-verbal way, teacher expectation is expressed unconsciously without words but facial expression, body language, and even the tone and pitch of the speaking, thus, it is usually hard to under control. Teacher expectation is delivered or passed to students through a variety of teacher behaviors as suggested by Good and Brophy (1987) [3] in the following behaviors:

(1) Teachers wait a longer time, giving cues or prompt when the higher-expected students answer questions, while less time with no cues or prompt for the lower-expected students.

(2) Teachers give more praise or less criticism to the higher-expected students with success or failure.

(3) Teachers show more interest and enthusiasm in the higher-expected students than in the lower expected students.

(4) Teachers often let the higher-expected students answer difficult questions.

(5) Teachers demand more from high-expected students in fulfilling study task.

(6) Teachers are more often show their nonverbal indications of support to the higher-expected students.

\section{Influential Factors of Teacher Expectation}

During the formation of teacher expectation many factors are involved. In classroom-teaching, students are the most direct and influential factors, which are involved with attitudes, competency levels, social and economic backgrounds. On the other hand, teachers' personalities, concepts, knowledge and attitudes towards students can not be ignored.

In China, English is mainly taught in classroom not practiced in daily life. The reaction of the students to the process of English teaching and their behaviors in class mainly depends on their English level. In this circumstance, teachers can easily distribute different expectations toward students on the basis of students' acceptance of the content of English classroom. Consequently, those students with poor spoken English but fast reading or high writing ability will probably get the low expectation from their teachers and when they perceive the judgment or expectation from their teachers, the confidence for learning English well will probably be weakened unconsciously.

Besides, there are other factors affecting the formation of teacher expectation in English teaching. Sex is one of the influential factors. Boys and girls should be given equal opportunities to speak in class and in other school environments, while boys are regarded as clumsy in learning a new language and thus get less opportunity to talk though they are expected to be more powerful than girls in science and technology. Appearance also has an influence and students' actual behaviors in school play a part in forming teacher expectation (Chang, Liu \& Wen 2004). [4]

Application of Teacher Expectancy Effect in English Teaching

As has stated above, teacher expectation can produce a great influence on students. With different expectations to different students, teachers tend to take different attitudes and actions to students. The influences of teacher expectation can be expressed in the following three aspects.

First, teacher expectation can greatly influence the confidence and self-fulfilling prophecy of students. Students with high expectations from teachers will get more encouragement and become more confident in English study and their later life. Second, teacher expectation can influence students' marks and behavior. Students with high expectation may be more aspired and study hard to get good marks. Students with lower expectation may be depressed and gradually give up. Third, the relationship between teachers and students is crucial to students both in the English teaching activities and students' progress. Students with high expectation feel close to teachers and a harmonious atmosphere between teachers and students is a must in English teaching. Thus, the goal of English teaching is to exert the positive teacher expectation effect and overcome the negative one to advance students' English.

\section{1) Establishing Harmonious Relationship with} Students

A close and harmonious relationship between teachers and students is crucial in English teaching and it is the most important factor affecting the formation of teacher expectation. Under an active and democratic learning atmosphere, it's easy for students to follow teachers and get into the world of English learning head over heel. On the contrary, if the learning atmosphere is dull, boring and depressed, students will be passive and reluctant to communicate with teachers and his partners. As a result, they will resist teachers' conduction and don't regulate their behaviors initiatively. In the process of English teaching, teachers should show good attitude toward students so as to help students exclude the mental barriers for study. Indifference and rudeness must be got rid of. Teachers should respect the personality of every student and treat them equally and believe that every student has his great development potential. After class, teachers should show their concern for students and come closer to them and know their joys and sorrows (Zhang 2012) [5].

As is mentioned in the previous paragraph, encouragement should be given to correct opinions and behaviors, and proper criticism for some actions is also in great need. Criticism in need is necessary. In most circumstances, teachers should tolerate with the mistakes of their students. However, over-criticism is not rational. Even when students give wrong answers, comfort and encouragement are needed instead of criticism. When learning a foreign language, students can not avoid making mistakes. English learning is no exception. When students make mistakes, teachers should not criticize them coldly or ironically, instead, teachers should encourage them and give them more chances to practice. For example, students often misuse "he" and "she" in speaking even when they are in the university. They also often encounter pronunciation problems such as "gr" in "Great Wall", "green" and "Greece" and so on. In these kinds of situations, teachers should be more patient and speak in a kind, mild and encouraging way. Students should be strengthened to be more confident and do not fear to make mistakes. After class, more communication should be 
made on purpose of inputting more useful information about students.

2) Developing Positive Expectations and Avoiding Negative Expectations

As is mentioned above, there are two kinds of teacher expectation effects: positive effect and negative effect. Both have great influence on students and it should be made clear that the positive expectation is the key for successful English learning and the purpose of English teaching is to exert the positive effect and overcome the negative one. In order to achieve this goal, some strategies should be taken to enhance positive effect and minimize negative effect.

First, teachers should be alert to set appropriate expectation according what he knows about the students and ensure them that everyone has great potential to make great progress and help them to set positive goals and they can do better if they put more efforts and time in English study. Second, teachers should guide students to perceive their own talents and stimulate and encourage them to achieve. By doing so, teachers should stress everyone's continuous progress and avoid comparing this student to that one. Teachers should also avoid evaluating student performance only when they make progress or failure and provide formative assessment timely. Third, Teachers ought to make flexible expectation and get ready to follow the appropriate instructional strategies and take strategies to guarantee that all students have equal opportunities to respond or participate. Only in way can teachers develop positive expectation and avoid negative expectation ( $\mathrm{Li}$ 2011) ${ }^{[6]}$.

\section{3) Teacher Expectation in English Classroom}

Classroom teaching is crucial in English learning and how to permeate teacher expectation in classroom teaching is of great importance. The following are the steps of the application in teacher expectation in classroom teaching.

\section{a) Teacher Expectation in Preparation}

Preparation for class is a workshop filled with teacher expectation. In this preliminary work in classroom, teachers apply their teaching theory and professional knowledge and skills into practice. This process is a guarantee for teaching quality and efficiency.

Before planning to organize the whole teaching, teacher should first have a clear idea about the English level of students and the problems they might meet with. Second, combining with the features of English lessons, teacher should consider how to inspire students' interest to learn English, lead them to think positively and participate actively (Hong 2010) ${ }^{[7]}$. Last, when writing the teaching plan, teacher should design different study objects for students of different level. English teaching is quite different with the teaching of other subjects. Learning a foreign language requires plenty of practice. So in English class teacher should try their best to make students speak and speak more. Thus, lost of activities should be designed before hand and the activities should be interesting, various, colorful and to the point. Those activities are designed with various objects, various teaching methods and openness answers, such as presentation, role play, debate, play, speech, or situational dialogues, etc. Teacher should try every means to inspire students' interest and make every student to participate or take a part. As to the students, they should preview the lesson that they are going to learn and have the questions in mind and go to English class with these questions and much enthusiasm.

\section{b) Teacher Expectation in Leading-in}

Leading-in is a second step of English teaching and an attracting and impressive leading-in may arouse the interest and attract attention of all the students and make them eager to know what is going. There are many ways to fulfill the leading-in task. Teacher may make suspense with questions to stimulate curiosity, interest of students (Babad 1993) ${ }^{[8]}$. The questions designed should be connected with the content of the lesson. For example, if the lesson is Life in Australia, teacher may raise question like "a. Have you ever been abroad?" Students may provide two answers "Yes" or "No". To the "Yes" one, teacher my go on asking "which country have you been?" student may have lot to say. To the "No" one, a question may be followed "which country do you want to visit, and why?" It's usually the case that questions designed by teacher beforehand may not be sufficient, teacher need to raise more questions to respond extempore. In addition to designed questions, teacher may transform different forms with English stories, jokes, anecdotes, favorite quotations, myths, paintings even music, animation and movies, etc. to stimulate learning motivation of students.

\section{c) Teacher Expectation in Designing and} Delivering Questions

Question plays a very important role in English classroom teaching. It is not only a method to evaluate teacher expectation effect but also a bridge between teacher and students to deliver teacher's expectation to students and give feedback to teacher. The quality of a question and question in proper time are the measures to value a teacher and his expectation effect. An experienced teacher will use questions to embody his expectation effect. Therefore, how to design and deliver a question of high teacher expectation effect remains a great challenge to teachers. The following are some suggestions:

(1) Proper question for proper students

Different students have different English levels, and question designed for them should be different. That is to say, teaches should develop different expectations for students according to their aptitudes. Teachers should find the zone of proximal development of students and difficult questions should be designed on the basis of students' knowledge. So when a student get praised after answering teacher's question, he will have a sense of success and want to do better next time and finally he can improve himself in English learning.

(2) Proper question at a proper time

Due to the difficulty of questions and different psychological states of students, teacher should ask questions at the proper time. For example, at the beginning of the class or the time students are absent-minded or the classroom atmosphere is not active or when referring to the key points and difficult points or summary at the end of the class (Hu 2011) ${ }^{[9]}$.

(3) Timely comment at a proper time

The amount of time teacher gives his students to answer is critical. When teacher asks a question, he should wait for a moment, if the student does not give the answer, teacher should not repeat the question again and again or ask another to answer, and he should wait for a proper time. After getting the answer, teacher should give a timely 
comment with proper evaluation, more affirmation and less negative, and, if possible, ask more questions, so that student can have enough time to supplement or modify his answer. At the same time, teacher should give eye contact to student, smiling with encouragement.

\section{d) Teacher Expectation in Discussion}

In English teaching, class discussion is necessary and it provides chances for students to participate in the teaching process. The teacher should take care to choose topics and deliver carefully it in a free and open way. Class discussion can enhance the social skills and social negotiation, foster interdependence and use more complex thinking strategies (Hu 2011) ${ }^{[9]}$. The topics chose by teacher should connect with the text, or a social hot issue, or any thing students have interest in. In the discussion, students can develop a more comprehensive consideration, understanding and cooperation. The ways for classroom discussion can arouse students' interest. At the end of the discussion, both the teacher and students should make a summary or comment (Hester, Roel, \& Margaretha 2010) [10]

\section{e) Teacher Expectation in Work Assessment}

Work assessment is reflection, adjustment of English teaching and it is also a feedback of teacher expectation effect. Work assessment or work correction with expectation is a good example of homework teaching. Work correction is a direct way for students to reflect their mistakes and it is a two-way communication between teacher and student. Beside the usual correction of the mistakes in students' homework, it's better for teacher to write some words with praise, encouragement, consideration and expectation which will bring confidence and enthusiasm to students. On the other hand, students will feel encouraged and grateful to teacher and very likely they will write back, and then the communication between teacher and students goes on and on. In this situation, work correction serves as a tool or a bridge between teacher and student. In this way teacher expectation effect is delivered successfully and unconsciously (Van Matre, Valentine \& Cooer 2000) ${ }^{[11]}$.

The ways that teachers evaluate students' work are critical for the establishment of adaptive motivational patterns. Such patterns focus more on the selfimprovement and achievement of objective standards of students. In contrast, evaluations that focus on social comparisons, which, unfortunately, are common practiced in many classrooms, can lose of motivation. For example, grading on a curve focuses quite explicitly on social comparisons. Such evaluations only inform students how their performance compares to other students. They provide little information about the extent to which students have mastered the required material (Deemer 2004) $)^{[12]}$.

All in all, teacher expectation is completely permeated in preparation, leading-in, and designing and delivering questions, classroom discussion and work assessment. English teaching is flexible, not only includes the above five steps and operational methods. English teachers should seek after better and more efficient ways and methods to make teacher expectation melt into English classroom teaching, and turn unconscious expectation into conscious expectation and enhance the expectation effects to the utmost.

\section{CONCLUSION}

As has stated above, teacher expectation plays a very important role in students' potential development and successful classroom teaching. And it is necessary for English teachers to apply teacher expectation in teaching flexibly and carefully. Yet positive teacher expectations do not necessarily lead to students' outstanding achievement, "anti-Rosenthal-Effect" phenomena also exist. In English teaching, student motivation, enthusiasm and achievement are influenced by multiple factors besides teacher expectation. Even if the teacher expects high, false judgment of students' autonomy, enforcing learning requirement and improper design of test papers, can also lead to the poor gains of students. Furthermore, teacher expectation for students can not be too high or too low and the time of achieving the expectation should be in reason and the way of the expectation also should be flexible ( $\mathrm{Hu}$ 2011).

How to apply this education concept into practice should adjust according to the current status in education field and need the teachers' effort. All in all, expectation education should be carried out in the classroom in a reasonable way. This paper only involves very limited number of subjects. There must be many other ways to make full use of Teacher Expectancy Effect in English teaching, yet the ways and methods of teacher expectation in this paper need to be further studied and proved. That is also the challenge to all English teachers.

\section{REFERENCES}

[1] Scott, G. The formation and effects of teachers' expectations on students. The Graduate College University of Wisconsin-Stout: 2001, p.17-24.

[2] Matters, Gray. More thanblack or white: the schooling experiences of black-white biracial students. Education and Urban Society, 2013, March 1, 45, p.175-207.

[3] Good, T. \& Brophy J. Looking in classrooms. New York: Harper \& Row, 1987.

[4] Chang L, Liu H, Wen Z, et al. Mediating teacher liking and moderating authoritative teaching on Chinese adolescents' perceptions of antisocial and pro-social behaviors. Journal of Educational Psychology, 2004, 96, 369- 380.

[5] Zhang Hongwei. What we can learn from researches on teachers' expectation effect. Journal of Huaihai Institute of Technology (Humanities \& Social Sciences Edition), 2012, 5, p.93.

[6] Li Hongjing. Foreign language teaching: psychological effects of teacher expectations. Journal of Lvliang University, 2011, 6, p.1112.

[7] Hong Youjuan. On the negative effect of teachers' expectation. Journal of Yunnan RTV University, 2010, 1, p.85-86.

[8] Babad, E. Pygmalion---25 years after interpersonal expectations in the class. In: P. D. Blanck(Ed). Interpersonal expectations: theory research and applications. New York: Cambridge University Press: 1993, 125- 175.

[9] Hu Wenting. An application study of expectation education in English teaching. The Graduate Thesis of Qufu Normal University: 2011, p.32-33, p35-36.

[10] Hester de Boer, Roel J. B. \& Margaretha P. C. Sustainability of teacher expectation bias effects on long-term student performance. Journal of Education Psychology, 2010, 168- 179.

[11] Van Matre J. C., Valentine J. C. \& Cooer H. Effect of students' after-school activities on teachers' academic expectancies. Contemporary Educational Psychology, 2000, 25, 167- 183.

[12] Deemer, S. A. Classroom goal orientation in high school classrooms: revealing links between teacher beliefs and classroom environment. Educational Research, 2004, 46, p.73-90. 